\title{
Application of PCR in the Detection of Aflatoxinogenic and Non- aflatoxinogenic Strains of Aspergillus Flavus Group of Cattle Feed Isolated in Iran
}

\author{
Sepideh Rahimi ${ }^{1}$, Noshin Sohrabi ${ }^{1}$, Mohammad Ali Ebrahimii ${ }^{1}$, Majid Tebyanian ${ }^{2}$, Morteza Taghi zadeh ${ }^{2}$ \\ \& Sahar Rahimi ${ }^{3}$ \\ ${ }^{1}$ Department of Plant Biotechnology, Tehran Shargh Branch, Faculty of Agriculture Payam Noor University, Iran \\ ${ }^{2}$ Department of Research and development, The Razi Vaccine and Serum Research Institute in the Hessarak \\ district in Karaj, Iran \\ ${ }^{3}$ Department of Food Science and Technology, Pharmaceutical Sciences branch Islamic Azad University, Tehran, Iran \\ Correspondence: Sepideh Rahimi, Department of Plant Biotechnology, Tehran Shargh Branch, Faculty of \\ Agriculture Payam Noor University, Iran E-mail: srahimi1919@gmail.com
}

Received: August 4, 2016

Accepted: August 17, 2016

Online Published: November 30, 2016

doi:10.5539/jmbr.v6n1p121

URL: http://dx.doi.org/10.5539/jmbr.v6n1p121

\begin{abstract}
Aflatoxins are among the most important Mycotoxins that are mainly produced by various Aspergillus species, specially Aspergillus flavus and Aspergillus parasiticus. Aflatoxins are carcinogenetic and immunosuppressive, so that can lead to acute liver damage, cirrhosis of the liver and hepatocarcinoma induction. Consuming the feed contaminated by Aspergillus puts humans and animals under the danger of Aflatoxins that are considered as an important threats for human and animal health. The purpose of the present study was to make distinction between Aflatoxinogenetic and non-Aflatoxinogenetic strains and Aspergillus Flavus using PCR and TLC and the expression of five Aflatoxin biosynthesis genes including aflD (nor-1), aflP( omtA), aflO (omtB), aflQ(ordA), aflR in 40 strains was investigated using PCR. In this study, a number of 40 Aspergillus flavus strains from 67 species of cattle feed from 21 industrial warehouses of various areas of Tehran and Alborz were used. After isolation and culture in exclusive environment of yeast extract of sucrose agar, the isolated Aspergillus strains were investigated by microscopic and macroscopic methods. In order to make distinction between Aflatoxinogenetic and nonAflatoxinogenetic strains, PCR method and TLC techniques were used. The results showed that only 7 strains (1, $3,5,14,22,34$, and 38) were Aflatoxin-producers fungi and the rest 33 samples were non-Afatoxin-producers fungi. Since Aspergillus flavus is the main contaminator of cattle feed, there is a need to develop a simple, rapid and sensitive method to identify Aflatoxigenetic fungi, particularly between Aflatoxinogenetic and nonAflatoxinogenetic strains of AF.
\end{abstract}

Keywords: Aflatoxinohenetic, non-Aflatoxinogenetic, Aspergillus flavus strains, PCR, TLC, Cattel feed

\section{Introduction}

Fungi growth in stored feed is one of the threatening factors of human health (Richard et al., 2003). The use of unhealthy cattle feed causes distortion in health cycle of cattle, people and diaries (Humans, Organization, \& Cancer, 2002). Various studies on cattle feed have shown that the contamination of cattle feed by fungi, particularly Aspergillus species, leads to the creation of Aflatoxin (J. W. Bennett \& Klich, 2003; Kamei \& Watanabe, 2005).

Aflatoxins are considered as secondary fungal metabolites that are easily created along the growth and storage of feed and are mainly produced by Aspergillus flavus, Aspergillus parasiticus, and Aspergillus nomius (K. C. Ehrlich, Montalbano, \& Cotty, 2003; Varga, Frisvad, \& Samson, 2009; Yu et al., 2004; Yu, Woloshuk, Bhatnagar, \& Cleveland, 2000).

Goldbatt reported that the death of more than one thousands turkeys in England was due to the contamination of Brazilian peanut meal poultry feed to Aspergillus and prtoducing Aflatoxin. This disease is caused by toxin produced by Aspergillus flavus on birds' feed (Wogan \& Pong, 1970). This toxin in 1961 led to more awareness regarding damages resulting from fungi toxins as the contaminator of food and causing disease or even death in 
humans and animals and years between 1960 and 1975 were the golden years of studies on fungi toxins, since scientists conducted many studies on these toxigenic factors (J. W. Bennett \& Klich, 2003).

Aflatoxins, compared to other fungi toxins, due to carcinogenicity and acute toxicity effects, are more important. Among the detrimental effects of Aflatoxins, we can mention weakening and destroying the immune system, genetic mutations and cancer (Chu, 1991; Richard et al., 2003). There are four main types of Aflatoxins including: AFB1, AFG1, AFB2 and AFG2 (J. Bennett, Kale, \& Yu, 2007; Murphy, Hendrich, Landgren, \& Bryant, 2006). Here, AFB1 is the most toxic one (Van Egmond, Schothorst, \& Jonker, 2007; Yu, Bhatnagar, \& Ehrlich, 2002). Among effective factors in producing Aflatoxins, we can refer to genetic and environmental factors such as the type of fungi, type of medium, humidity, temperature, growth, storage, ventilation, light, carbon source, and $\mathrm{pH}$. At least 23 enzymatic reactions contribute in Aflatoxin synthesis oath. The synthesis of this toxin is done through a series of oxidation and rehabilitation reactions. The Aflatoxin biosynthetic pathway involves approximately 25 genes clustered in a $70 \mathrm{~kb}$ DNA region (Bhatnagar, Cary, Ehrlich, Yu, \& Cleveland, 2006; Scherm, Palomba, Serra, Marcello, \& Migheli, 2005).

Most of these genes are regulated by the specific path of the protein binding to DNA (AflR) and are produced by aflR gene (Chang, Horn, \& Dorner, 2005; Yu et al., 1995). Due to the toxic and carcinogenetic characteristics of Aflatoxins, there is an immediate need for a rapid method. There are sensitive and particular methods for detecting Aflatoxigentic matters in feed and the conventional methods to make distinction between toxigenetic and nontoxigenetic isolations in Aspergillus flavus including fungi culture in suitable medium, extracting Aflatoxins by organic solvents and monitoring their presence by chromatographic techniques (Abbas et al., 2004; Fente, Ordaz, Vazquez, Franco, \& Cepeda, 2001; Sforza, Dall'Asta, \& Marchelli, 2006). The current methods used for monitoring the presence of Aflatoxins are time consuming and labor intensive.

Recently, DNA-based detection systems are introduced as powerful tools to detect and identify Aflatoxin (Geisen, 1996). The Polymerase Chain Reaction (PCR) is among the selected methods for this purpose (Criseo, Bagnara, \& Bisignano, 2001; Färber, Geisen, \& Holzapfel, 1997; Shapira et al., 1996; Sweeney, Pàmies, \& Dobson, 2000). Unique DNA sequences of the respective fungus have to be chosen as primer binding sites concluded that genes involved in the Aflatoxin biosynthetic pathway (Geisen, 1996; Scherm et al., 2005). The purpose of the present study was to make distinction between Aflatoxinogenetic and non-Aflatoxinogenetic strains using PCR and TCL and the expression of aflD (nor-1), aflP( omtA), aflO (omtB), aflQ(ordA), aflR in 40 strains was investigated using PCR.

\section{Materials and Methods}

\subsection{Fungal Strains and Culture}

A number of 40 Aspergillus flavus strains from a collection of 67 species from cattle feed including maize (A), domestic barly (B1), imported barly (B2), wheat bran (D) and soybean meal (E) were collected from 21 industrial warehouses of Tehran and Alborz.

Strains were cultured on sabouraud detrose agar (SDA) medium containing chloramphenicol (to prevent the growth of bacteria and yeasts) and plates were incubated at the temperature of $28-30{ }^{\circ} \mathrm{C}$ for $3-5$ days. After the emergence of colony, the fungal spores were transmitted to yeast extract of sucrose agar (YES) (Samson, Hoekstra, \& Frisvad, 2004). All plates were incubated at the temperature of $25{ }^{\circ} \mathrm{C}$ for one week. Then, the growing strains in each plate were put under microscopic and macroscopic investigations using valid identification keys (Klich \& Pitt, 1988).

\subsection{Determination of Aflatoxin Production by Chromatography}

Therefore, $500 \mathrm{ul}$ of samples were mixed by $250 \mathrm{ul}$ of chloroform. Then, they were dotted on TLC plate of silica gel, so that the distance of dots with the lower margin of chromatography plate was approximately $2 \mathrm{~cm}$ and these dots were dried at the temperature of $27^{\circ} \mathrm{C}$. After that, $50 \mathrm{ml}$ extraction solvent (containing $40 \mathrm{ml}$ toluene, $7 / 5 \mathrm{ml}$ methanol and $2 / 5 \mathrm{ml}$ acetic acid) were added to the solvent tank, so that the depth of solvent should be at the bottom of the tank, less than $2 \mathrm{~cm}$. The TLC plate is placed in tank and let the solvent be $4-5 \mathrm{~cm}$ higher than the dotted line (about 15 to 20 minutes). Then, bring the TLC plate out of the solvent tank to be dried and observable under ultraviolet light (365 nm). An Aflatoxingenic strain was used a positive control.

\subsection{Molecular Characterization}

2.3.1 Detection of Aflatoxin Genes aflD (nor-1), aflP( omtA), aflO (omtB), aflQ(ordA) and aflR

In this study, common naming system of Aflaxotin genes was used by (Cary, Ehrlich, Bland, \& Montalbano, 2006; K. Ehrlich, Yu, \& Cotty, 2005; Yu et al., 2004). The performance of these five genes is indicated in Table 1. 
Table 1. Aflatoxin biosynthetic genes and functions ${ }^{\mathrm{a}}$

\begin{tabular}{|c|c|c|c|}
\hline Old name & New name & Enzyme/product & Function in the pathway \\
\hline norl & $a f l D$ & NOR reductase & $\begin{array}{l}\text { norsolorinic acid }(N O R) \rightarrow \\
\text { averantin }(A V N)\end{array}$ \\
\hline omtA & aflP & O-methyltransferase $A$ & $\begin{array}{l}\text { sterigmatocystin }(S T) \rightarrow \\
\text { O-methylsterigmatocystin }(O M S T)\end{array}$ \\
\hline omtB & aflO & O-methyltransferase $B$ & $\begin{array}{l}\text { DHDMST (dihydrodemethylsterigmatocystin) } \rightarrow \\
\text { DHST (dihydrosterigmatocystin) }\end{array}$ \\
\hline $\operatorname{ord} A$ & aflQ & Oxydoreductase & $\begin{array}{l}\text { O-methylsterigmatocystin }(O M S T) \rightarrow A F B 1 \text { and } A F G 1, \\
\text { dihydro-Omethylsterigmatocystin }(D H O M S T) \rightarrow A F B 2 \text { and } A F G 2\end{array}$ \\
\hline aflR & aflR & $\begin{array}{l}\text { Transcription activator } \\
\text { AflR }\end{array}$ & Pathway regulator \\
\hline
\end{tabular}

${ }^{a}$ Clustered pathway genes in aflatoxin biosynthesis (Cary et al., 2006; K. Ehrlich et al., 2005; Yu et al., 2004).

\subsection{DNA Extraction}

To extract DNA, some microliters of spore suspension of Aspergillus isolate were kept, transferred to the plate containing YES, and a one-week colony is employed. 500 microliters lysis buffer (containing 1 mollar Tris-HCI $(\mathrm{PH}=8), 0.5$ mollar EDTA $(\mathrm{Ph}=8)$ and $7.45 \mathrm{~g} \mathrm{KCI})$, a pile of about $60 \mathrm{mg}$ mycelium was added from Aspergillus colony and then crushed by hand and vortex for 45 seconds and finally centrifuged for 10 minutes at $5000 \mathrm{~g}$. The supernatant liquid was transferred to new fresh tube, and 300 microliters cold isopropanol (kept below $-20^{\circ} \mathrm{C}$ ) was added and finally cell lysis and isopropanol were mixed through multiple reversal activities of microtube and centrifuged for 10 minutes at $12000 \mathrm{~g}$. The supernatant liquid was discarded and about 0.8 microliter 70 degree alcohol was added to sediment and after 15 minutes was incubated at $37^{\circ} \mathrm{C}$. Eventually, 50 microliters deionized distilled water was added to the remaining sediment, and then DNA was mixed with distilled water by gently tapping. The resulting liquid is frozen and stored at $-20^{\circ} \mathrm{C}$ as a pure DNA solution.

\subsection{PCR Amplification}

In the present study, five pairs of primers were designed based on Aspergillus flavus sequences from aflD (nor-1), aflP( omtA), aflO (omtB), aflQ(ordA), aflR using OLIGO7 software (Scherm et al., 2005). Oligonucleotides were made by Macro-Gene Company. The primer sequences are presented in Table 2.

Table 2. Sequences of the nucleotide primers used in this study

\begin{tabular}{|c|c|c|c|c|}
\hline Primer code & Target gene & Primer sequences & PCR product size (bp) & Accession no \\
\hline $\begin{array}{l}\text { AflD-1for } \\
\text { AflD-2rev }\end{array}$ & aflD(nor-1) & $\begin{array}{l}\text { 5'- CTCATCACACGCAGGCATCGG -3' } \\
\text { 5'- AGATGCCTGCCACACTGTCT -3' }\end{array}$ & 702 & FN398169.1 \\
\hline $\begin{array}{l}\text { AflP-1for } \\
\text { AflP-2rev }\end{array}$ & aflP(omtA) & $\begin{array}{c}\text { 5'- CCCATCTCGATAGCGCCTG -3' } \\
\text { 5'- GCCACCCATACCTAGATCAAAGC -3' }\end{array}$ & 611 & FN398191.1 \\
\hline $\begin{array}{l}\text { AflO-1for } \\
\text { AflO-2rev }\end{array}$ & aflO $(o m t B)$ & $\begin{array}{l}\text { 5'- TTACGATTTGATGGAGCAGG -3' } \\
\text { 5'- AGGTTCTCTTGGCTACAG -3' }\end{array}$ & 358 & HM355030.1 \\
\hline $\begin{array}{l}\text { AflQ-1for } \\
\text { AflQ-2rev }\end{array}$ & $\operatorname{afl} Q(\operatorname{ord} A)$ & $\begin{array}{l}\text { 5'- AACATTCTCTGCCTCATCACT -3' } \\
\text { 5'- TCGCTCTGGCTTGAACACC -3' }\end{array}$ & 445 & Ay510451.1 \\
\hline $\begin{array}{l}\text { AflR-1for } \\
\text { AflR-2rev }\end{array}$ & aflR & $\begin{array}{l}\text { 5'- AGAGCTACTGAACGTCCCAT -3' } \\
\text { 5'- ATCAGGTTGCACGAACTGTCC -3' }\end{array}$ & 1458 & AF441430.2 \\
\hline
\end{tabular}

About 5 microliters of extracted DNA, 1 microliters of forward and revers primers, 10 microliters of PCR master mix prepared by Amplicon Company (containing $0.2 \mathrm{U} / \mu 1$ of Taq DNA polymerase, 0.4 milimolar of dATP and dNTP (dTTP, dCTP, dGTP and 3 milimolar of $\mathrm{MgCl} 2$ ) and necessary amount of sterile deionized distilled water (ddH20) were added until achieving the final volume of 20 microliters. The heating program of PCR was done according to 错误!未找到引用源。.

Table 3. Heat program used for PCR

\begin{tabular}{|c|c|c|c|c|c|}
\hline & 1 cycle & & 34 cycle & & 1 cycle \\
\hline \multirow{2}{*}{ PCR steps } & Initial denaturation & Denaturation & Annealing & Extention & Final extention \\
\hline & Time & Time & Time & Time & Time \\
\hline
\end{tabular}




\begin{tabular}{lllllllllll} 
aflD & $95{ }^{\circ} \mathrm{C}$ & $3 \mathrm{~min}$ & $95{ }^{\circ} \mathrm{C}$ & $30 \mathrm{sec}$ & $61.4{ }^{\circ} \mathrm{C}$ & $40 \mathrm{sec}$ & $72{ }^{\circ} \mathrm{C}$ & $30 \mathrm{sec}$ & $72{ }^{\circ} \mathrm{C}$ & $7 \mathrm{~min}$ \\
aflP & $95{ }^{\circ} \mathrm{C}$ & $3 \mathrm{~min}$ & $95{ }^{\circ} \mathrm{C}$ & $30 \mathrm{sec}$ & $60{ }^{\circ} \mathrm{C}$ & $45 \mathrm{sec}$ & $72{ }^{\circ} \mathrm{C}$ & $45 \mathrm{sec}$ & $72{ }^{\circ} \mathrm{C}$ & $7 \mathrm{~min}$ \\
aflO & $95{ }^{\circ} \mathrm{C}$ & $3 \mathrm{~min}$ & $95{ }^{\circ} \mathrm{C}$ & $30 \mathrm{sec}$ & $52.4{ }^{\circ} \mathrm{C}$ & $30 \mathrm{sec}$ & $72{ }^{\circ} \mathrm{C}$ & $30 \mathrm{sec}$ & $72{ }^{\circ} \mathrm{C}$ & $7 \mathrm{~min}$ \\
aflQ & $95{ }^{\circ} \mathrm{C}$ & $3 \mathrm{~min}$ & $95{ }^{\circ} \mathrm{C}$ & $30 \mathrm{sec}$ & $57 \circ^{\circ} \mathrm{C}$ & $30 \mathrm{sec}$ & $72{ }^{\circ} \mathrm{C}$ & $45 \mathrm{sec}$ & $72{ }^{\circ} \mathrm{C}$ & $7 \mathrm{~min}$ \\
aflR & $95{ }^{\circ} \mathrm{C}$ & $2 \mathrm{~min}$ & $95{ }^{\circ} \mathrm{C}$ & $30 \mathrm{sec}$ & $58 \circ^{\circ} \mathrm{C}$ & $45 \mathrm{sec}$ & $72{ }^{\circ} \mathrm{C}$ & $1: 30 \mathrm{~min}$ & $72{ }^{\circ} \mathrm{C}$ & $7 \mathrm{~min}$ \\
\hline
\end{tabular}

\section{Results and Discussion}

Aspergillus flavus strains were grown on yeast extraction of sucrose agar at the temperature of $25^{\circ} \mathrm{C}$ for one week. In the present study, another set of primers exclusive for aflR was used. This gene has a very important role in biosynthesis path of Aflatoxin by regulating the activities of other structural genes such as nor-1, omtA, omtB and ordA (Chang, Yu, Bhatnagar, \& Cleveland, 1999; Woloshuk et al., 1994).

PCR was applied for these genes using five sets of primers. Figure 1 (A-E) shows products of PCR obtained from each primer. A series of bands from aflD (nor-1), aflP( omtA), aflO (omtB), aflQ(ordA) and aflR can be observed in $702,611,358,445$, and $1458 \mathrm{bp}$. Nine strains $(1,2,3,5,13,14,22,34$ and 38) show a similar pattern that indicates the presence of all five genes and other strains show different patterns. The obtained results by TLC were investigated. Only 7 strains $(1,3,5,14,22,34$ and 38$)$ were Aflatoxin-producers fungi and other 33 samples were non-Aflatoxin producers fungi. TLC method has shown a clear distinction between Aflatoxin-producing and nonproducing Aspergillus flavus. The results obtained by PCR and TLC are compared in 错误!未找到引用源。 .
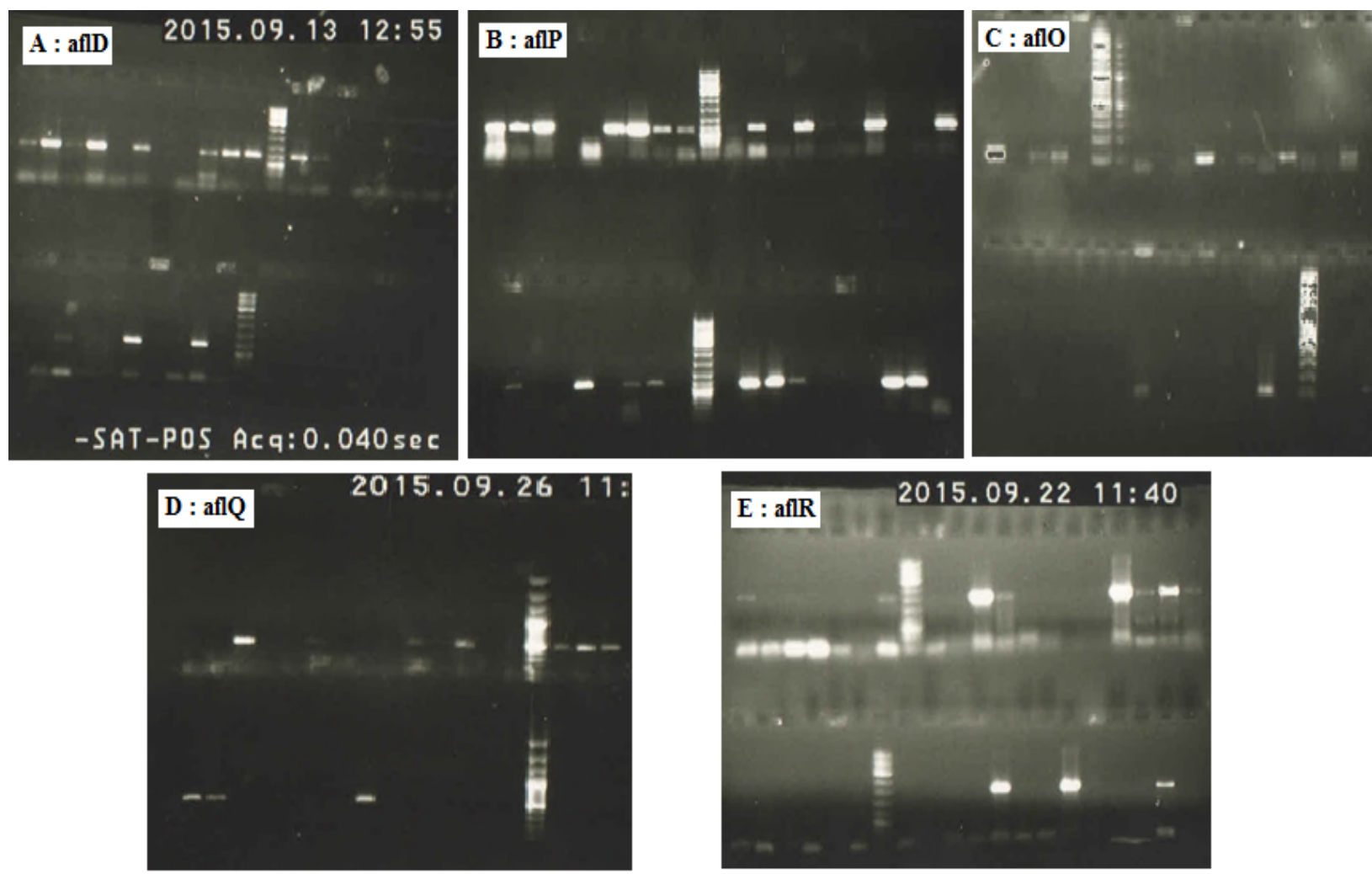

Figure 1. The images of gel electrophoresis of PCR products for expression of genes (aflD, aflP, aflO, aflQ and aflR) of Aspergillus isolated from cattle feed in $1 \%$ agarose gel and ladder $1 \mathrm{~kb}$

Table 3. This table indicates a comparison between the conventional and molecular methods (TLC and PCR) on aflatoxin production

\begin{tabular}{|c|c|c|}
\hline Sample & PCR results & $\begin{array}{c}\text { Aflatoxin } \\
\text { production by } \\
\text { TLC* method }\end{array}$ \\
\hline
\end{tabular}




\begin{tabular}{|c|c|c|c|c|c|c|c|}
\hline $\begin{array}{c}\text { Sample } \\
\text { Type }\end{array}$ & Strain No. & aflR & aflP & aflo & aflQ & $a f l D$ & $\begin{array}{l}\text { Alfaotoxin } \\
\text { production }\end{array}$ \\
\hline 1:B2 & 1 & + & + & + & + & + & Positive \\
\hline 1:B2 & 2 & + & + & + & + & + & Negative \\
\hline 1:B2 & 3 & + & + & + & + & + & Positive \\
\hline 1:E & 4 & - & - & + & + & + & Negative \\
\hline $2: \mathrm{B} 1$ & 5 & + & + & + & + & + & Positive \\
\hline 2:B2 & 6 & - & + & - & + & - & Negative \\
\hline $2: \mathrm{E}$ & 7 & + & + & + & + & - & Negative \\
\hline $3: \mathrm{B} 2$ & 8 & + & - & + & + & - & Negative \\
\hline $3: \mathrm{E}$ & 9 & + & + & + & + & - & Negative \\
\hline 4:A & 10 & - & + & + & + & - & Negative \\
\hline $4: \mathrm{A}$ & 11 & - & - & + & + & - & Negative \\
\hline $5: \mathrm{B} 2$ & 12 & + & - & + & + & - & Negative \\
\hline $5: D$ & 13 & + & + & + & + & + & Negative \\
\hline $5: \mathrm{E}$ & 14 & + & + & + & + & + & Positive \\
\hline $6: \mathrm{E}$ & 15 & + & + & + & - & + & Negative \\
\hline 7:A & 16 & - & + & + & + & + & Negative \\
\hline 7:A & 17 & - & - & + & + & - & Negative \\
\hline 7:D & 18 & + & + & + & - & - & Negative \\
\hline $8: \mathrm{B} 1$ & 19 & + & + & + & - & - & Negative \\
\hline 9:A & 20 & + & + & + & - & - & Negative \\
\hline $9: \mathrm{B} 2$ & 21 & + & + & + & + & - & Negative \\
\hline 9:D & 22 & + & + & + & + & + & Positive \\
\hline 9:D & 23 & + & + & - & - & - & Negative \\
\hline 9:D & 24 & - & + & + & - & + & Negative \\
\hline 10:B1 & 25 & + & - & + & + & + & Negative \\
\hline $10: \mathrm{E}$ & 26 & + & + & + & - & - & Negative \\
\hline $11: \mathrm{A}$ & 27 & - & + & + & + & - & Negative \\
\hline $11: \mathrm{E}$ & 28 & + & - & + & + & - & Negative \\
\hline $12: \mathrm{B} 1$ & 29 & + & + & + & + & - & Negative \\
\hline $13: \mathrm{B} 1$ & 30 & + & + & + & - & - & Negative \\
\hline $13: D$ & 31 & + & + & + & + & - & Negative \\
\hline $14: \mathrm{A}$ & 32 & - & + & + & + & - & Negative \\
\hline $15: \mathrm{A}$ & 33 & + & - & + & + & - & Negative \\
\hline $15: \mathrm{B} 2$ & 34 & + & + & + & + & + & Positive \\
\hline $15: \mathrm{D}$ & 35 & - & + & + & + & + & Negative \\
\hline $19: B 2$ & 36 & - & - & + & + & - & Negative \\
\hline 19:D & 37 & - & + & + & + & - & Negative \\
\hline $20: A$ & 38 & + & + & + & + & + & Positive \\
\hline $20: A$ & 39 & - & + & - & - & - & Negative \\
\hline 20:D & 40 & - & - & + & + & - & Negative \\
\hline \multicolumn{2}{|c|}{ Control } & + & + & + & + & + & Positive \\
\hline
\end{tabular}

*TLC: Thin layer chromatography.

The purpose of the present study was to standardize and optimize PCR method to make distinction between Aflatoxinogenetic and non-aflatoxinogenetic strains of Aspergillus flavus that produce Aflatoxins by effective genes in biosynthesis path. For this purpose, we worked on 40 strains of Aspergillus flavus selected from 67 species of cattle feed from 21 warehouses of Tehran and Alborz as the samples of this study and an standard strain of Aspergillus flavus 5004 as a positive control to examine TLC and PCR. The procedure was conducted by aflD (nor-1), aflP (omtA), aflO (omtB), aflQ (ordA) and aflR. Nor-1, omtA, omtB and ordA are four structural gens in gene cluster in Aflatoxin biosynthesis path that code key regulating enzymes in Aflatoxin production. As a result, they are necessary for Aflatoxin production (Yabe \& Nakajima, 2004; Yu et al., 2004). After DNA extraction, the heating program of each PCR cycle was optimized within specific time using previous studies (Criseo et al., 2001; Färber et al., 1997; Geisen, 1996; Shapira et al., 1996). 
The results showed that 5 primers, constituted sharp and distinct bands in certain area. Another studies show regulating Aflatoxin biosynthesis in Aspergillus containing a complex pattern of positive and negative transcription regulating factors that are under the influence of nutritional and environmental parameters (Chang, Yu, Bhatnagar, \& Cleveland, 2000; K. C. Ehrlich et al., 2003; Flaherty \& Payne, 1997; Takahashi et al., 2002). The results showed that seven samples of 40 Aspergillus flavus species were positive using TLC and in general, 40 samples with the five mentioned primers were positive using PCR technique and positive control in both methods was positive, as well. The same results were obtained using PCR and multiplex PCR (Criseo et al., 2001; Shapira et al., 1996). The results showed that PCR is a sensitive, rapid and specific method in Aflatoxinogenetic molds detection, but it cannot make distinction between toxigenic and non-toxigenic fungi. According to the results of this study regarding non-Aflatoxin producing strains, there is not any relationship between the obtained results by PCR and conventional methods. Lack of Aflatoxin production is related to an incomplete pattern in PCR. This proposes that various types of mutations can deactivate Aflatoxin biosynthesis path of these strains. Geisen (1996) stated that the lack of Aflatoxin production can be the result of substitution of some bases (Geisen, 1996). Also, Liu and Chu (1998) showed that various physiologic conditions can be effective in Aflatoxin biosynthesis (Liu \& Chu, 1998). In this study, it was observed that we can refer to PCR as a screening test for initial isolation regarding high sensitivity and speed (100\%). The positive samples should be more investigated such as chromatography and RT-PCR. RT-PCR is a complementary measurement of PCR and the presence of gene. Mayer et al. (2003) and Sweeney et al. (2000) suggested that the presence and absence of mRNA could allow direct distinction between them (Mayer, Färber, \& Geisen, 2003; Sweeney et al., 2000).

In this regard, multiplex RT-PCR by having the advantage of unique response to expressing several genes enclosed in the biosynthesis of Aflaxotin and real experimental time of RT-PCR can be used for fungi growth kinetic and the presence of designed AFB simultaneously. However, none of these methods has yet been applicable to make distinction between non-taxogenic and taxogenic strains of Aspergillus flavus.

\section{Conclusion}

Since investigations show that the highest pollution of cattle feed is related to toxigenic Aspergillus, therefore, there is need for developing a simple, rapid and sensitive method to detect Aflatoxigentic fungi, particularly, making distinction between Aflatoxin-producing and non-producing strains of AF. As a result, we can prevent the entrance of Aflatoxin to the health cycle of human and cattle.

\section{References}

Abbas, H. K., Zablotowicz, R., Weaver, M., Horn, B., Xie, W., \& Shier, W. (2004). Comparison of cultural and analytical methods for determination of aflatoxin production by Mississippi Delta Aspergillus isolates. Canadian Journal of Microbiology, 50(3), 193-199.

Bennett, J., Kale, S., \& Yu, J. (2007). Aflatoxins: background, toxicology, and molecular biology Foodborne diseases (pp. 355-373): Springer.

Bennett, J. W., \& Klich, M. (2003). Mycotoxins. Clinical Microbiology Reviews, 16(3), 497-516. doi: 10.1128/CMR.16.3.497-516.2003

Bhatnagar, D., Cary, J. W., Ehrlich, K., Yu, J., \& Cleveland, T. E. (2006). Understanding the genetics of regulation of aflatoxin production and Aspergillus flavus development. Mycopathologia, 162(3), 155-166.

Cary, J. W., Ehrlich, K. C., Bland, J. M., \& Montalbano, B. G. (2006). The aflatoxin biosynthesis cluster gene, aflX, encodes an oxidoreductase involved in conversion of versicolorin A to demethylsterigmatocystin. Applied and environmental microbiology, 72(2), 1096-1101.

Chang, P.-K., Horn, B. W., \& Dorner, J. W. (2005). Sequence breakpoints in the aflatoxin biosynthesis gene cluster and flanking regions in nonaflatoxigenic Aspergillus flavus isolates. Fungal Genetics and Biology, 42(11), 914-923.

Chang, P.-K., Yu, J., Bhatnagar, D., \& Cleveland, T. E. (1999). The Carboxy-Terminal Portion of the Aflatoxin Pathway Regulatory Protein AFLR of Aspergillus parasiticus ActivatesGAL1:: lacZ Gene Expression inSaccharomyces cerevisiae. Applied and environmental microbiology, 65(6), 2508-2512.

Chang, P.-K., Yu, J., Bhatnagar, D., \& Cleveland, T. E. (2000). Characterization of the Aspergillus parasiticus major nitrogen regulatory gene, areA. Biochimica et Biophysica Acta (BBA)-Gene Structure and Expression, 1491(1), 263-266.

Chu, F. S. (1991). Mycotoxins: food contamination, mechanism, carcinogenic potential and preventive measures. Mutation Research/Genetic Toxicology, 259(3), 291-306. 
Criseo, G., Bagnara, A., \& Bisignano, G. (2001). Differentiation of aflatoxin-producing and non-producing strains of Aspergillus flavus group. Letters in applied microbiology, 33(4), 291-295.

Ehrlich, K., Yu, J., \& Cotty, P. (2005). Aflatoxin biosynthesis gene clusters and flanking regions. Journal of Applied Microbiology, 99(3), 518-527.

Ehrlich, K. C., Montalbano, B. G., \& Cotty, P. J. (2003). Sequence comparison of aflR from different Aspergillus species provides evidence for variability in regulation of aflatoxin production. Fungal Genetics and Biology, 38(1), 63-74.

Färber, P., Geisen, R., \& Holzapfel, W. (1997). Detection of aflatoxinogenic fungi in figs by a PCR reaction. International journal of food microbiology, 36(2), 215-220.

Fente, C., Ordaz, J. J., Vazquez, B., Franco, C., \& Cepeda, A. (2001). New additive for culture media for rapid identification of aflatoxin-producingAspergillus strains. Applied and environmental microbiology, 67(10), 4858-4862.

Flaherty, J. E., \& Payne, G. A. (1997). Overexpression of aflR leads to upregulation of pathway gene transcription and increased aflatoxin production in Aspergillus flavus. Applied and environmental microbiology, 63(10), 3995-4000.

Geisen, R. (1996). Multiplex polymerase chain reaction for the detection of potential aflatoxin and sterigmatocystin producing fungi. Systematic and Applied Microbiology, 19(3), 388-392.

Humans, I. W. G. o. t. E. o. C. R. t., Organization, W. H., \& Cancer, I. A. f. R. O. (2002). Some traditional herbal medicines, some mycotoxins, naphthalene and styrene: World Health Organization.

Kamei, K., \& Watanabe, A. (2005). Aspergillus mycotoxins and their effect on the host. Medical mycology, 43(sup1), 95-99.

Klich, M., \& Pitt, J. (1988). Differentiation of Aspergillus flavus from A. parasiticus and other closely related species. Transactions of the British Mycological Society, 91(1), 99-108.

Liu, B.-H., \& Chu, F. S. (1998). Regulation of aflR and its product, AflR, associated with aflatoxin biosynthesis. Applied and environmental microbiology, 64(10), 3718-3723.

Mayer, Z., Färber, P., \& Geisen, R. (2003). Monitoring the production of aflatoxin B1 in wheat by measuring the concentration of nor-1 mRNA. Applied and environmental microbiology, 69(2), 1154-1158.

Murphy, P. A., Hendrich, S., Landgren, C., \& Bryant, C. M. (2006). Food mycotoxins: an update. Journal of food science, 71(5), R51-R65.

Richard, J., Payne, G., Desjardins, A., Maragos, C., Norred, W., \& Pestka, J. (2003). Mycotoxins: risks in plant, animal and human systems. CAST Task Force Report, 139, 101-103.

Samson, R. A., Hoekstra, E. S., \& Frisvad, J. C. (2004). Introduction to food-and airborne fungi: Centraalbureau voor Schimmelcultures (CBS).

Scherm, B., Palomba, M., Serra, D., Marcello, A., \& Migheli, Q. (2005). Detection of transcripts of the aflatoxin genes aflD, aflO, and aflP by reverse transcription-polymerase chain reaction allows differentiation of aflatoxin-producing and non-producing isolates of Aspergillus flavus and Aspergillus parasiticus. International Journal of Food Microbiology, 98(2), 201-210.

Sforza, S., Dall'Asta, C., \& Marchelli, R. (2006). Recent advances in mycotoxin determination in food and feed by hyphenated chromatographic techniques/mass spectrometry. Mass Spectrometry Reviews, 25(1), 54-76.

Shapira, R., Paster, N., Eyal, O., Menasherov, M., Mett, A., \& Salomon, R. (1996). Detection of aflatoxigenic molds in grains by PCR. Applied and environmental microbiology, 62(9), 3270-3273.

Sweeney, M. J., Pàmies, P., \& Dobson, A. D. (2000). The use of reverse transcription-polymerase chain reaction (RT-PCR) for monitoring aflatoxin production in Aspergillus parasiticus 439. International journal of food microbiology, 56(1), 97-103.

Takahashi, T., Chang, P.-K., Matsushima, K., Yu, J., Abe, K., Bhatnagar, D., ... Koyama, Y. (2002). Nonfunctionality of Aspergillus sojae aflR in a strain of Aspergillus parasiticus with a disrupted aflR gene. Applied and environmental microbiology, 68(8), 3737-3743.

Van Egmond, H. P., Schothorst, R. C., \& Jonker, M. A. (2007). Regulations relating to mycotoxins in food. Analytical and bioanalytical chemistry, 389(1), 147-157. 
Varga, J., Frisvad, J., \& Samson, R. (2009). A reappraisal of fungi producing aflatoxins. World Mycotoxin Journal, 2(3), 263-277.

Wogan, G. N., \& Pong, R. S. (1970). AFLATOXINS*. Annals of the New York Academy of Sciences, 174(2), 623635.

Woloshuk, C., Foutz, K., Brewer, J., Bhatnagar, D., Cleveland, T., \& Payne, G. A. (1994). Molecular characterization of aflR, a regulatory locus for aflatoxin biosynthesis. Applied and environmental microbiology, 60(7), 2408-2414.

Yabe, K., \& Nakajima, H. (2004). Enzyme reactions and genes in aflatoxin biosynthesis. Applied Microbiology and Biotechnology, 64(6), 745-755.

Yu, J., Bhatnagar, D., \& Ehrlich, K. C. (2002). Aflatoxin biosynthesis. Revista iberoamericana de micología, 19(4), 191-200.

Yu, J., Chang, P.-K., Cary, J. W., Wright, M., Bhatnagar, D., Cleveland, T. E., ... Linz, J. E. (1995). Comparative mapping of aflatoxin pathway gene clusters in Aspergillus parasiticus and Aspergillus flavus. Applied and environmental microbiology, 61(6), 2365-2371.

Yu, J., Chang, P.-K., Ehrlich, K. C., Cary, J. W., Bhatnagar, D., Cleveland, T. E., ... Bennett, J. W. (2004). Clustered pathway genes in aflatoxin biosynthesis. Applied and environmental microbiology, 70(3), 1253-1262.

Yu, J., Woloshuk, C. P., Bhatnagar, D., \& Cleveland, T. E. (2000). Cloning and characterization of avfA and omtB genes involved in aflatoxin biosynthesis in three Aspergillus species. Gene, 248(1), 157-167.

\section{Copyrights}

Copyright for this article is retained by the author(s), with first publication rights granted to the journal.

This is an open-access article distributed under the terms and conditions of the Creative Commons Attribution license (http://creativecommons.org/licenses/by/4.0/). 